\title{
Prompt Payment of Bookdealers' Invoices: An Approach to Standards
}

$M r$. Bennett, librarian, University of Arizona, was formerly head of the acquisitions department, Columbia University Libraries.

$\mathrm{D}$ UNIVERSITY libraries make payment as promptly as they should for materials supplied by bookdealers and subscription agents? Can standards acceptable to both dealer and librarian be constructed for measuring a library's performance in this area?

A survey of bookdealers' expectations, undertaken in June I95 I to provide a basis for setting standards, is reported in the first section below. Factors affecting the construction of appropriate standards, viewed in relation to dealers' expectations, are discussed in a second section, and standards tentatively suggested. Finally, in order to test the practicability of these standards, one university library's performance in processing invoices is analyzed and evaluated.

\section{Bookdealers' Expectations}

The survey grew out of an attempt to analyze the relative promptness with which the acquisitions department of Columbia University Libraries processes bookdealers' invoices for payment. Analysis had permitted description of departmental performance but, in the absence of any formal standards, evaluation was impossible except in purely subjective terms. The first step in any attempt to formulate standards, it seemed obvious, was to consult the group most directly affected by any failure on the part of libraries to make payment reasonably promptly.

Questionnaires were mailed to 96 bookdealers $(6 \mathrm{I}$ in the U.S.; 35 in countries abroad) selected at random from a card file in the department. Usable replies were received from 54 of the domestic dealers $(89 \%)$ and from 22 of the foreign dealers $(63 \%)$. Ninety per cent of the responses from domestic dealers were returned within Io days, and $91 \%$ of the replies from foreign dealers within the roughly comparable period of 40 days.

The first question asked was, "How soon after date of invoice do you believe payment for books should be in your hands?" The same phrasing was employed in a second question, which focussed upon payment for periodical subscriptions and continuations. Respondents were asked in each case to check a pre-coded time-interval.

The distribution of responses is shown in Table I. As was expected, the responses of foreign dealers differed significantly from those of domestic dealers, because of obvious differences in the amounts of time required for shipping books from, and transmitting payment to, dealers abroad. Within each group, responses relating to book invoices differed from those relating to serials invoices.

The median expectation of domestic dealers was 30 days for payment of book invoices, and 45 days for serials invoices. The median expectation of foreign dealers was 60 days for each invoice category. A more satisfactory measure can be secured by weighting

TABLE I

Dealers' Expectations With Respect to Payment of Book and Serials Invoices

\begin{tabular}{|c|c|c|c|c|c|c|c|c|}
\hline \multirow{2}{*}{$\begin{array}{l}\text { No. of days } \\
\text { from date of } \\
\text { invoice to } \\
\text { receipt of } \\
\text { payment }\end{array}$} & \multicolumn{4}{|c|}{ ic Dealers } & \multicolumn{4}{|c|}{ Foreign Dealers } \\
\hline & \multicolumn{2}{|c|}{$\begin{array}{c}\text { Book } \\
\text { Invoices } \\
\text { (No.) }(\%)\end{array}$} & \multicolumn{2}{|c|}{$\begin{array}{c}\text { Serials } \\
\text { Invoices* } \\
\text { (No.) (\%) }\end{array}$} & \multicolumn{2}{|c|}{$\begin{array}{c}\text { Book } \\
\text { Invoices } \\
(\text { No.) }(\%)\end{array}$} & \multicolumn{2}{|c|}{$\begin{array}{l}\text { Serials } \\
\text { Invoices* } \\
\text { (No.) (\%) }\end{array}$} \\
\hline I & 0 & 0 & 2 & 5 & 0 & 0 & 0 & 0 \\
\hline 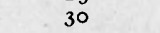 & 29 & 54 & I 7 & 40 & & 9 & & 21 \\
\hline 4 & I 6 & & 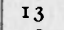 & 3 & & & & 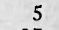 \\
\hline 6 & 7 & 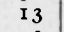 & 9 & 21 & & & $J$ & 21 \\
\hline$\stackrel{9 c}{N c}$ & 2 & 3 & 2 & 4 & 8 & 3 & 9 & 47 \\
\hline Applic & $\circ$ & $\circ$ & I I & 一 & $\circ$ & ० & 3 & 一 \\
\hline & 54 & 100 & 54 & 100 & 22 & $\infty 0$ & 22 & 100 \\
\hline Aver & & & & & & ys & & \\
\hline
\end{tabular}

* "Not Applicable" responses disregarded in calculating percentages and averages. 
the responses in each cell by the length of interval (number of days) and computing average expectations for each category. The results of these computations are shown at the bottom of Table I. Weighting in this fashion assumes that even if dealers had been asked to state their expectations freely, they would have tended to state them in intervals similar to those provided in the questionnaire.

For both domestic and foreign dealers, the difference in average expectations with respect to invoices for books and serials is not significant: $4 \mathrm{I}$ and 43 days for domestic dealers; 66 and 67 days for foreign dealers. In order to simplify the construction of standards based on such expectations, and recognizing that close approximations are satisfactory in handling data of this sort, it is asserted that the average domestic dealer expects payment within 42 days, and the average foreign dealer within 67 days, after date of invoice.

Although the questions posed in the questionnaire were stated in generalized terms, it cannot be assumed that the expectations stated by respondents in this survey apply to all university libraries in the U.S. They apply principally, and perhaps exclusively, to Columbia University Libraries. It appears reasonable to assert, however, that standards derived from an analysis of these expectations may be applicable also to other libraries located no more than Io days' shipping distance from their major domestic sources of supply.

\section{Standards for Library Performance}

Any attempt to specify standard intervals within which a university library should complete its processing of invoices must take into account certain variables outside the control of the library.

$V$ ariables Affecting Standard-setting.-The major variable is distance between library and dealer, and its chief dependent variables, the amount of time required for delivery of materials and invoices and for transmittal of payment. The university library which is located near a large book-trade center is obviously in a better position to meet a 42 -day expectation of payment on domestic invoices than is a library located at a considerable distance from such a center. With as little as two or three days required for shipping materials and one day for transmitting payment, the more favorably located library whose business office is able to process payment within a reasonably short period may be able to allow as long as 28 days for processing an invoice. If, on the other hand, as much as 10 days are required for shipping materials and 5 days for transmitting payment, the library may have to shorten its processing period to Io or II days in order to meet a domestic dealers' expectation of payment within 42 days. Similar assertions must be made in considering the amount of time a library may allow for its processing of foreign dealers' invoices.

Another important variable, as suggested briefly above, is the amount of time the university's business office requires for final processing. Some university business offices may be able to dispatch payment within a week after the library has forwarded an invoice, while others may require two or three weeks. Even greater delays may be necessary in periods of peak activity.

State universities ordinarily have central business offices in which only a portion of the final processing is accomplished. Invoices approved first by the library and then processed by the local business office must generally be forwarded to a disbursing office in the state capital. The libraries of such institutions can scarcely hope to meet the expectations of dealers unless they are in a position to accession materials the same day they arrive, and forward invoices to the university's business office within one or two days.

An Approach to Standards. - The way in which these variables operate to the disadvantage of (I) libraries located at moderate or considerable distances from their sources of supply, and (2) libraries in universities whose business offices are unable to process payment within a relatively short time, makes hazardous any attempt to construct standards of general applicability. The only satisfactory approach appears to lie in specifying a formula which can be applied in individual libraries. The elements in such a formula are the dealer's expectation (E); average shipping time $(S)$; average time required for business-office processing (B); average time required for transmitting payment $(\mathrm{P})$; the amount of time the library may allow for processing $(L)$, and still meet the dealer's 
TABLE II

Time Allowances Within Which Libraries Located at Varying Distances from Sources of Supply Can Meet Dealers' Expectations

\begin{tabular}{|c|c|c|c|c|}
\hline $\begin{array}{l}\text { Dealer's } \\
\text { Expecta- } \\
\text { tion }\end{array}$ & $\begin{array}{l}\text { Ship_ } \\
\text { ping } \\
\text { Time }\end{array}$ & $\begin{array}{l}\text { Business } \\
\text { ()ffice } \\
\text { Process- } \\
\text { ing }\end{array}$ & $\begin{array}{l}\text { Trans- } \\
\text { mittal } \\
\text { Time }\end{array}$ & $\begin{array}{l}\text { Allow- } \\
\text { ance for } \\
\text { Library }\end{array}$ \\
\hline $\mathrm{Days}^{2}$ & $\begin{array}{r}3 \\
3 \\
3 \\
3 \\
5 \\
5 \\
5 \\
5 \\
8 \\
8 \\
8 \\
8 \\
10 \\
10 \\
10 \\
10\end{array}$ & $\begin{array}{l}10 \\
\text { I } 2 \\
14 \\
16 \\
10 \\
12 \\
14 \\
16 \\
10 \\
12 \\
14 \\
16 \\
10 \\
12 \\
14 \\
16\end{array}$ & $\begin{array}{l}\text { I } \\
\text { I } \\
\text { I } \\
\text { I } \\
2 \\
2 \\
2 \\
2 \\
4 \\
4 \\
4 \\
4 \\
5 \\
5 \\
5 \\
5\end{array}$ & $\begin{array}{l}28 \\
26 \\
24 \\
22 \\
25 \\
23 \\
21 \\
19 \\
20 \\
18 \\
16 \\
14 \\
17 \\
15 \\
13 \\
11\end{array}$ \\
\hline $\begin{array}{c}67 \\
\text { Days }\end{array}$ & $\begin{array}{l}2 \text { I } \\
2 \text { I } \\
2 \text { I } \\
2 \text { I } \\
25 \\
25 \\
25 \\
25 \\
29 \\
29 \\
29 \\
29 \\
33 \\
33 \\
33 \\
33\end{array}$ & $\begin{array}{l}10 \\
12 \\
14 \\
16 \\
10 \\
12 \\
14 \\
16 \\
10 \\
12 \\
14 \\
16 \\
10 \\
12 \\
14 \\
16\end{array}$ & $\begin{array}{l}10 \\
10 \\
10 \\
10 \\
12 \\
12 \\
12 \\
12 \\
14 \\
14 \\
14 \\
14 \\
16 \\
16 \\
16 \\
16\end{array}$ & $\begin{array}{r}26 \\
24 \\
22 \\
20 \\
20 \\
18 \\
16 \\
14 \\
14 \\
12 \\
10 \\
8 \\
8 \\
6 \\
4 \\
2\end{array}$ \\
\hline
\end{tabular}

expectation. Stated in symbolical terms, the formula reads: $\mathrm{E}-(\mathrm{S}+\mathrm{B}+\mathrm{P})=\mathrm{L}$.

In Table II differing values have been given the elements in the formula, in an attempt to illustrate the approximate range of timeallowances that might serve as "standards" for individual libraries. The range of assigned values is based upon the experience of Columbia, and may or may not be wholly realistic in terms of the experience of other libraries. It is probable that most university libraries in the U.S. will be able to apply this formula within the range of values suggested; i.e., that most of them receive their shipments from domestic dealers in from 3 to Io days, and from foreign dealers in from 21 to 33 days; and that most business offices can process invoice-payments in from IU to 16 days. ${ }^{1}$

\section{Performance Measurement at Columbia}

The analysis of Columbia University $\mathrm{Li}$ braries' performance is based upon invoices processed during two sample periods: (I) an 8 -week period (24 November I95 I through I 8 January 1952) during which a total of I606 invoices was processed; and (2) a 4week period (27 February through $25 \mathrm{March}$ 1952) during which 99I invoices were processed. There is evidence to support a claim of representativeness for the combined sample of 2597 invoices. Its composition differs only slightly from that of samples analyzed earlier (in November-December 1950 and in MayJune I95I); e.g., $48 \%$ of the total sample were domestic book invoices as compared with $50 \%$ in each of the earlier samples, and $25 \%$ were domestic serials invoices as compared with $23 \%$ and $25 \%$ in earlier analyses.

During the sample periods accessions clerks followed standard departmental routines, processing invoices continuously as materials were accessioned. Invoices were approved, signed and forwarded to the Controller's Office on a daily basis.

The focus of analysis was entirely upon library performance. All invoices received in the mail were dated upon receipt; shipping labels on all shipments were stamped with date of receipt, and this date transcribed on the invoice covering the shipment. For each invoice processed during the two sample periods, a time-interval was calculated from the date on which the library was first in a position to process it (i.e., receipt-of-invoice date, or the receipt-of-shipment date, whichever was later) to the date on which it was forwarded to the Controller's Office for payment.

During the first sample period, timeintervals were tallied by hand according to invoice-categories alone. For the second sample, a code-sheet designed to provide broader analytical scope was employed, and the data punched on IBM cards. For the central portion of the analysis the data for

\footnotetext{
1 It is suggested that business officers of a university
can take measures (e.g., revamped procedures, augmented staff) designed to ensure dispatch of payment within 16 days or less after an approved invoice has been forwarded by the library.
} 
TABLE III

Cumulative Proportions of Invoices for Books and Serials From Domestic and Foreign Dealers Approved for Payment Within Specific Time-Intervals

\begin{tabular}{|c|c|c|c|c|c|c|c|c|c|}
\hline \multirow{2}{*}{$\begin{array}{l}\text { Interval from } \\
\text { receipt of materials } \\
\text { and/or invoices to } \\
\text { date of approval }\end{array}$} & \multicolumn{3}{|c|}{ Book Invoices } & \multicolumn{3}{|c|}{ Serials Invoices } & \multicolumn{3}{|c|}{ All Invoices } \\
\hline & $\begin{array}{c}\text { Domestic } \\
(\%)\end{array}$ & $\begin{array}{l}\text { Foreign } \\
(\%)\end{array}$ & $\begin{array}{l}\text { Total } \\
(\%)\end{array}$ & $\begin{array}{c}\text { Domestic } \\
(\%)\end{array}$ & $\begin{array}{l}\text { Foreign } \\
(\%)\end{array}$ & $\begin{array}{l}\text { Total } \\
(\%)\end{array}$ & $\begin{array}{l}\text { Domestic } \\
(\%)\end{array}$ & $\begin{array}{l}\text { Foreign } \\
(\%)\end{array}$ & $\begin{array}{l}\text { Total } \\
(\%)\end{array}$ \\
\hline $\begin{array}{l}4 \text { days } \\
7 \text { days } \\
\text { Io days } \\
\text { I } 4 \text { days } \\
20 \text { days } \\
31 \text { days }\end{array}$ & $\begin{array}{l}36 \\
71 \\
85 \\
92 \\
95 \\
97\end{array}$ & $\begin{array}{l}19 \\
47 \\
70 \\
82 \\
91 \\
95\end{array}$ & $\begin{array}{l}32 \\
65 \\
81 \\
89 \\
94 \\
97\end{array}$ & $\begin{array}{l}35 \\
6 \mathrm{I} \\
83 \\
89 \\
94 \\
97\end{array}$ & $\begin{array}{l}31 \\
50 \\
76 \\
84 \\
90 \\
93\end{array}$ & $\begin{array}{l}34 \\
57 \\
81 \\
87 \\
94 \\
96\end{array}$ & $\begin{array}{l}36 \\
67 \\
84 \\
91 \\
95 \\
97\end{array}$ & $\begin{array}{l}24 \\
48 \\
73 \\
83 \\
9 \mathrm{I} \\
95\end{array}$ & $\begin{array}{l}33 \\
62 \\
81 \\
89 \\
94 \\
96\end{array}$ \\
\hline $\begin{array}{l}\text { Number of Invoices } \\
\qquad(\mathrm{N}=100 \%)\end{array}$ & $124 \mathrm{I}$ & 399 & $16_{4} 0$ & $66 \mathrm{I}$ & 296 & 957 & 1902 & 695 & 2597 \\
\hline
\end{tabular}

both samples are combined and presented in Table III.

Findings.-The cumulated percentage figures reveal that serials invoices are processed as promptly as book invoices, but that the processing of invoices from foreign dealers tends to lag behind that of invoices from domestic dealers, particularly in the shorter intervals. During the sample periods the library processed $91 \%$ of all domestic invoices within I 4 days, as compared with $83 \%$ of all foreign invoices within the same interval; and, within 20 days, $95 \%$ of domestic invoices as compared with $91 \%$ of foreign invoices.

This difference can probably be explained chiefly in terms of a general lack of language facility among invoice-clerks in the library. A psychological selection factor possibly operates also to the disadvantage of foreign invoices; clerks, preferring to work with invoices rendered in their own language, may tend to defer action on foreign invoices. Other factors which may help to explain the differences are: (I) an inherent difficulty in converting foreign currencies; and (2) the modes of bibliographic citation sometimes employed by foreign dealers.

The hypothesis that multiple-item invoices are processed less promptly than those for one or two items only was tested during the second sample period. The results of the analysis are shown in Table IV, in which it is revealed that $46 \%$ of all one-or-two-item invoices are processed within four days, as compared with $37 \%$ of three-to-five-item invoices and $28 \%$ of those for six or more items. As the time-intervals lengthen, however, this difference steadily diminishes. Cross tabula- tions were made to detect whether this difference resulted simply from a higher proportion of multiple-item invoices in the foreign group, but the variable was found to operate independently. Differences with respect to domestic and foreign invoices

\section{TABLE IV}

Cumulative Proportions of Invoices Approved for Payment within Specific Time-Intervals, According to Number of Items on Invoices

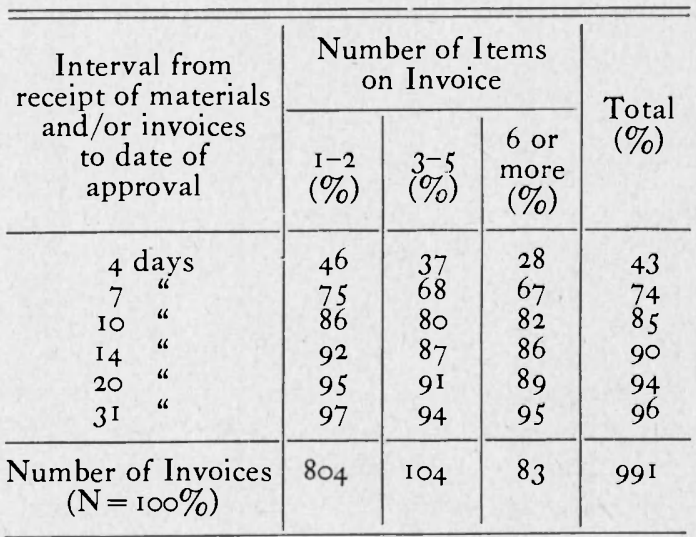

NB: Tables IV and V are based solely upon the second sample period.

narrowed somewhat in the one-or-two-item group, but remained clearly visible in all groups.

This finding is of little significance at Columbia, where $80 \%$ of all invoices received are for one or two items only, but it might be of considerable significance in a library where there is a higher proportion of invoices for three or more items. 
Evaluation of Performance.-It has been found that, on the average, five days are required for shipping domestic materials and approximately 25 days for shipping foreign materials to Columbia University Libraries. It has also been found (I) that the Controller's Office at Columbia generally requires 12 days for processing invoice-payments; and (2) that the average time required for transmitting payments to domestic dealers is two days, and 12 days for payments sent abroad. Substituting these known values in the formula suggested above, the time-allowances that can safely be permitted are found to be 23 days for domestic invoices and 18 days for foreign invoices. In order to simplify the evaluation process, however, the writer has chosen to employ a "standard" of 20 days for both categories.

The analysis shown in Table III reveals that, with respect to domestic invoices, the library came within $5 \%$ of meeting the standard for book invoices, and within $6 \%$ for serials invoices. Performance with respect to foreign invoices was on a slightly lower level. Nine per cent of foreign book invoices and $10 \%$ of foreign serials invoices remained to be processed by the end of a 20day period. Adjudged in terms of this relatively lenient standard, Columbia's performance was highly satisfactory.

Since most libraries are more distant from their sources than Columbia is, and would be obligated to process invoices within shorter time-allowances, an evaluation of Columbia's performance against a Io-day standard should throw considerable light upon the question of whether university libraries in general would be able to meet dealers' expectations. When appraised on the basis of the shorter ro-day standard, analysis shows that the library failed to process $15 \%$ of all domestic book invoices, and $17 \%$ of all domestic serials invoices, within Io days. Thirty per cent of foreign book invoices, and $24 \%$ of foreign serials invoices required more than Io days for complete processing. Adjudged by this more severe standard, it cannot be asserted that Columbia's performance was satisfactory.

The possibility that Columbia's performance may be fairly typical suggests the advisability of incorporating a tolerance factor into any set of standards which might be evolved. The reasonableness of permitting a tolerance of between $15 \%$ and $20 \%$ is underscored by analytical findings examined below.

Reasons for Delay.-The analysis of Columbia's invoice-payment performance in the first sample period indicated, as had two preliminary analyses, that despite strong efforts to make the processing of all invoices effectively prompt, a certain proportion of them require a longer processing period. In the second sample period, therefore, an attempt was made to ascertain the reasons for delays of more than ten days. Several pre-coded reasons were set down on checklist memoranda, and space provided for writing in reasons other than those listed. Invoiceclerks were instructed to attach one of these, appropriately checked, to each invoice whose

TABLE V

Reasons for More Than Ten Days' Delay in Processing Some Domestic and Foreign Invoices

\begin{tabular}{|c|c|c|c|c|c|c|c|c|c|}
\hline \multirow{2}{*}{ Reasons for delay } & \multicolumn{3}{|c|}{ Domestic Invoices } & \multicolumn{3}{|c|}{ Foreign Invoices } & \multicolumn{3}{|c|}{ All Invoices } \\
\hline & $\begin{array}{c}\text { Books } \\
(\%)\end{array}$ & $\begin{array}{c}\text { Serials } \\
(\%)\end{array}$ & $\begin{array}{l}\text { Total } \\
(\%)\end{array}$ & $\begin{array}{c}\text { Books } \\
(\%)\end{array}$ & $\begin{array}{c}\text { Serials } \\
(\%)\end{array}$ & $\begin{array}{l}\text { Totals } \\
(\%)\end{array}$ & $\begin{array}{c}\text { Books } \\
(\%)\end{array}$ & $\begin{array}{c}\text { Serials } \\
(\%)\end{array}$ & $\begin{array}{l}\text { Total } \\
(\%)\end{array}$ \\
\hline $\begin{array}{l}\text { Operational Deficiency in } \\
\text { Library } \\
\text { Operational Deficiency in } \\
\text { Dealer's Establishment } \\
\text { Operational Exigency in } \\
\text { the Library }\end{array}$ & $\begin{array}{l}3 \cdot 3 \\
0.2 \\
9.6\end{array}$ & $\begin{array}{l}2.5 \\
3.8 \\
7 \cdot 3\end{array}$ & $\begin{array}{l}3.0 \\
I .4 \\
8.9\end{array}$ & $\begin{array}{l}6.8 \\
2.0 \\
15.5\end{array}$ & $\begin{array}{r}0.8 \\
1.7 \\
10.8\end{array}$ & $\begin{array}{r}4 . I \\
\text { I. } 8 \\
\text { I } 3.5\end{array}$ & $\begin{array}{r}4.1 \\
0.6 \\
\text { I I. } 0\end{array}$ & $\begin{array}{l}2.0 \\
3.1 \\
8.5\end{array}$ & $\begin{array}{l}3 \cdot 3 \\
\text { I. } 6 \\
\text { IO. I }\end{array}$ \\
\hline $\begin{array}{l}\text { Proportion of Invoices Re- } \\
\text { quiring More than Ten } \\
\text { Days for Processing }\end{array}$ & I $3 . I$ & I 3.6 & I 3.3 & $24 \cdot 3$ & I 3.3 & 19.4 & I 5.7 & 13.6 & I 5.0 \\
\hline $\begin{array}{l}\text { Total Number of Invoices } \\
(\mathrm{N}=100 \%)\end{array}$ & 489 & 234 & 723 & $I_{4} 8$ & I 20 & 268 & 637 & 354 & $99 \mathrm{I}$ \\
\hline
\end{tabular}


processing had required more than ten days.

For purposes of analysis, reasons have been grouped into three main categories. In the list which follows, the reasons which accounted for more than three delays during the second sample period are italicized.

r. Operational Deficiencies in Library

a. Order card incorrect, incomplete or misfiled.

b. Invoice received in acquisitions department; materials received in departmental library.

c. Invoice and materials arrived at different times; clerk failed to match invoice against notice-of-receipt in vendor's file.

d. Faulty communication between library departments; e.g., invoice destined for Medical Library mis-directed to Law Library.

2. Operational Deficiencies in Dealer's Esta'lishment.

a. Part of material listed but not supplied.

b. Material or serial title not clearly identified.

c. Library's order number (s) not cited; or incorrectly cited.

d. Dealer supplied part of series without authorization; volume had to be referred to a departmental librarian for acceptance.

e. Dealer supplied on cancelled order; decision to reactivate order had to be referred to a departmental librarian.

f. Invoice incorrectly rendered; e.g., wrong title, or wrong volume numbers cited, necessitating correspondence with dealer.

3. Operational Exigencies in Library

a. Order had to be re-coded in different order-number series; $\iota . g$. , order placed in belief title comprised single volume, but found to be part of a set.

b. Order records temporarily in bindery, necessitating delay in recording of receipt and invoice-payment.

c. Farmington Plan invoice, requiring assignment of fund-account to be debited.

d. Serials and books listed on same invoice; two divisions of acquisitions department and/or one or more departmental libraries involved in processing payment.

e. Books submitted on approval; had to be referred to departmental library for acceptance.

f. Subscription price-increase seemed excessive; invoice held for verification of new rate.

g. Vendor specified payment be made to different payee, necessitating special handling. h. Absence of invoice-clerk because of illness.

i. Invoices had to be referred to departmental library for approval, because of long-standing policy.

The results of the analysis are shown in Table $V$. The final column indicates that delays in processing are more often assignable to operational deficiencies in the library than in the dealer's establishment, but that delays are caused much more of ten by deterrents over which, for one reason or another, neither librarian nor dealer can exert effective control.

Examination of specific reasons reveals, for example, that nine invoices $(0.9 \%)$ were delayed because an invoice-clerk was absent due to illness, and eleven ( $1.1 \%$ ) because of the necessity, midway in the sample period, for having the order-record bound. The largest single group of delayed invoices $(6.8 \%)$ were those which, because of long-standing policy, were processed in two large departmental libraries instead of in the central acquisitions unit.

The only other sizeable group of delayed invoices is one which the writer, perhaps with insufficient justification, designated for inclusion in the library-deficiency category. Fifteen invoices $(1.5 \%)$, received in the central acquisitions unit, were for materials shipped directly to a departmental library. In the absence of any notice of receipt from the latter, the invoices were filed to await receipt of shipment in the central unit, and were not investigated until approximately two weeks later. Two solutions to this kind of problem suggest themselves: (I) To ask dealers always to specify on their invoices the address to which they shipped materials if shipment was not addressed to the central acquisitions department; and (2) To request departmental librarians always to notify the central acquisitions department immediately when such shipments are delivered to them.

This portion of the analysis, it is believed, will help dealers to understand why, almost inevitably, a small proportion of their invoices are not, and possibly cannot be, processed by libraries within the relatively short timeallowance of ten days. Dealers will probably agree that, in the light of these findings, their expectations of payment should be modified, and that the practicability of a set of stand(Continued on page 39.5) 
electrical outlets and supervision by the audio-visual librarian. Students are assigned by the reading instructors to use the accelerators on an individual basis. There is a special collection of books on the tables with the accelerators and recommended for use with them. These books were chosen by the reading instructors for their reading content and have word counts in them so that rates on the accelerators can be immediately determined by the students without computation.

The audio-visual department also provides mechanical maintenance for the accelerators as well as for the tachistoscopes, ophthalmographs, and other devices used in the reading classes. The library dispatches student operators to deliver this equipment to instructors so that it is set up and ready for immediate use. The reading instructors and the audio-visual librarian work very closely together to work out problems involving technical equipment and audiovisual materials.

Though the library has already adapted its resources and abilities to the new reading program, it plans to expand its services. As the reading program becomes more extensive, the library services will undoubtedly become greater and more varied to meet the new demands of the program. The library has formulated plans for increased reading activities including a separate area for reading students which will be equipped with accelerators, special books, materials, and other devices.

The school or college library will probably make its greatest contribution to the expanded interest in reading by performing its usual function of directly integrating itself with the teaching program. When new courses, workshops and other curriculums concerned with reading are instituted, the academic library will play a role as important as those which it plays in traditional courses and academic activities. Only by constantly adapting itself to school and college needs, can the library continue to perform its basic educational function.

\section{Prompt Payment of Bookdealers' Invoices}

\section{(Continued from page 392)}

ards depends upon the incorporation of a tolerance factor. Standards might then be stated in some such terms as these: "If a university library processes $85 \%$ of all invoices within ten days and the remainder within a month, its performance may be adjudged highly satisfactory."

\section{Conclusion}

Implicit throughout this discussion is the premise that promptness in processing fayment for library materials is essential to the maintenance of strong, cordial relationships between dealers and libraries. Motivated by a desire to promote mutual understanding between partners in an enterprise of considerable importance to academic communities, an attempt has been made to explore the possibility of constructing standards acceptable to both.

An analysis of Columbia University $\mathrm{Li}$ braries' performance in this area indicates that the standards tentatively evolved may be applicable to a majority of university libraries in the U.S. Their general applicability and adoption, however, must wait upon reports of library investigations other than the one reported here.

A separate analysis of invoices requiring longer than ten days to process suggests (I) that dealers' expectations do not take fully into account certain factors which are not subject to effective control, and (2) that the practicability of any adopted standards depends upon the incorporation of a realistic tolerance factor. 